\title{
Manufacturing of Stabilized Soil Bricks
}

\author{
Bhudev Pandey ${ }^{1}$, Neelesh Kumar Singh ${ }^{2}$ \\ ${ }^{I}$ (UG Student, Civil Engg. Department, SRMGPC, Lucknow, Uttar Pradesh, India) \\ ${ }^{2}$ (Assistant Professor, Civil Engg. Department, SRMGPC, Lucknow, Uttar Pradesh, India)
}

\begin{abstract}
The main purpose of this paper is the development of low cost housing structures, in rural as well as in urban areas. In present scenario, the cost of construction of houses is going to be high, so it is difficult to make their homes at low cost especially for rural population. The clay bricks are generally high in cost and create pollution during burning process in kiln. So, in this paper, the reuse of fly ash and foundry sand is done as replacement of major amount of clay which will reduce the cost as well as pollution. No burning is required while making of this brick. For economic construction, we tried to replace the class A clay brick at very low cost by this brick. In this, we replace the major amount of clay by the fly ash and foundry sand with the cement and plasticizer. The strength of brick is comparatively more than class A brick at low cost by the composition of $33.33 \%$ of foundry sand, $40 \%$ of fly ash, $15 \%$ of cement and $5 \mathrm{gm}$ of plasticizer. Compressive strength of brick sample is tested at 5 days after removing the sample from mould.
\end{abstract}

Keywords: Fly ash, foundry sand, strength, cement, low cost, brick.

\section{Introduction}

In India, the use of clay brick is very common. But with the use of clay bricks, the fertility of land is getting affected because during excavation process the top layer of minerals gets excavated. The huge land required for manufacturing of clay bricks and also during burning process, the problem of pollution is generated. On the other hand, the production of foundry sand and fly ash is also huge so the waste management is becoming a serious issue in now days. With the use of these two wastes in bricks, reduces the cost of bricks and also reduce the disposing cost of the wastes, so the overall cost of construction could get low and the amount of clay could be reduced.

Amit Kumar D. Raval, Arti Pamnani, Alefiya I. Kachwala ${ }^{[1]}$ studied partial replacement of fine aggregate with foundry sand. They analysed the compressive strength of concrete block by $0 \%, 10 \%, 20 \%$, $30 \%, 40 \%, 50 \%$ at different curing periods ( 7 days, 14 days and 28 days). The compressive strength of concrete increased along with the foundry sand replacement up to $30 \%$. At $30 \%$ replacement of fine aggregate with foundry sand, maximum strength was $33.65 \mathrm{MPa}$.

The idea "use of foundry sand in bricks" was generated from there because foundry sand is high silica sand and the due to presence of high silica content the strength is also good enough.

\section{Material used}

1. OPC: The ordinary Portland cement of grade 43, used in this brick for binding and strength purposes.

2. Foundry sand: It is the by-product of metal and non-metal casting industries. The sand produced after the several operations of moulding. In this silica content is in high amount which imparts the strength.

3. Clayey soil: Clayey soil is very fine material having clay content. And the size of clay particle is less than $0.002 \mathrm{~mm}$

4. Plasticizer: Plasticizer is that material which imparts the plasticity as well as strength. In this we use silicon pe plasticizer.

5. Fly ash: It is by-product or waste generated from thermal power plants after the coal combustion.

The preparation of brick mix done by following:

\section{Methodology}

1. First, we collect the materials and weigh it.

2. We mix the material properly in dry state and then add sufficient amount of water in dry mix and mixed both properly.

3. The prepared mix is then poured into brick mould of size $26 * 13.4 * 7.3 \mathrm{~cm}$. During pouring, we tamped it time to time to prevent the formation of void and then finally, we placed the mould onto the vibrating machine.

4. After vibrating process, we left the sample for a day in exposed environment for sun drying. And then remove the brick sample from the mould.

5. After this we placed the brick sample into the oven for $10-12 \mathrm{hrs}$ at $108-110 \mathrm{c}$ to remove the excess moisture content. 
6. Then for 5 days, we cured the sample and then perform the compressive strength test on it.

7. The size of brick sample is $23.4 * 11.2 * 6.3 \mathrm{~cm}$.

\subsection{Test results of foundry sand}

\section{Result and Discussion}

Table 1: Properties of Foundry sand

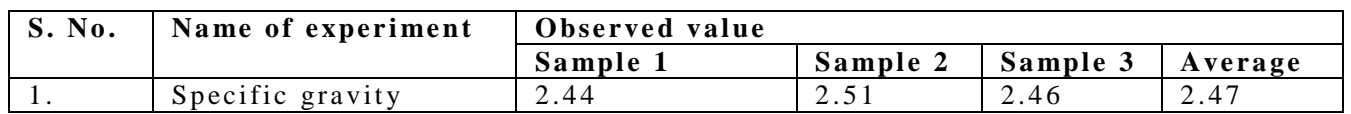

4.1.1. Grain size test of foundry sand:

Table 2: Grain size test of foundry sand

\begin{tabular}{|l|l|l|l|l|l|}
\hline Sizeof grain & $\begin{array}{l}\text { Weight of grain } \\
\text { retained } \\
(\mathbf{g m})\end{array}$ & $\begin{array}{l}\text { Weight retained, } \\
\text { in \% }\end{array}$ & $\begin{array}{l}\text { Cumulative weight } \\
\text { retained(gm) }\end{array}$ & $\begin{array}{l}\text { Cumulative } \\
\text { Weight retained, in \% }\end{array}$ & \% finer \\
\hline $1 \mathrm{~mm}$ & 16 & 3.85 & 16 & 3.85 & 96.15 \\
\hline $600 \mu$ & 9 & 2.16 & 25 & 6.01 & 93.99 \\
\hline $450 \mu$ & 89 & 21.394 & 114 & 27.404 & 72.596 \\
\hline $300 \mu$ & 133 & 31.97 & 247 & 59.019 & 40.981 \\
\hline $150 \mu$ & 144 & 34.615 & 391 & 93.634 & 6.366 \\
\hline $75 \mu$ & 6 & 1.442 & 397 & 95.076 & 4.924 \\
\hline Pan & 19 & 4.567 & 416 & 99.643 & 0.357 \\
\hline
\end{tabular}

$\mathbf{D}_{60}=300+((450-300) *(60-40.981) /(72.596-40.981)=390.23$ micron

Similarly, $\mathbf{d}_{10}=165.747$ micron

$\mathbf{d}_{\mathbf{3 0}}=252.415$ micron

Coefficient of uniformity, $\mathbf{c}_{\mathbf{u}}=\mathbf{d}_{\mathbf{6}_{0}} / \mathbf{d}_{\mathbf{1 0}}=2.352$

Coefficient of curvature, $\mathbf{c}_{\mathbf{c}}=\mathbf{d}_{\mathbf{3 0}}{ }^{2} /\left(\mathbf{d}_{60} * \mathbf{d}_{\mathbf{1 0}}\right)=0.9850$

The sand is poorly graded or uniform.

\subsection{Test results of clayey soil}

Table 3: Test results of clayey soil

\begin{tabular}{|l|l|l|l|l|l|}
\hline S. & Name of experiment & \multicolumn{3}{|l|}{ Observed value } \\
\cline { 3 - 6 } No. & & Sample 1 & Sample 2 & Sample 3 & Average \\
\hline 1. & Specific gravity & 2.43 & 2.44 & 2.42 & 2.44 \\
\hline
\end{tabular}

\subsection{Tests result on cement}

Table 4: Test results of clayey soil

\begin{tabular}{|l|l|l|l|l|l|}
\hline S. No. & Name of experiment & Observed value & \multicolumn{4}{l|}{} \\
\cline { 3 - 6 } & & Sample 1 & Sample 2 & Sample 3 & Average \\
\hline 1. & Initial setting time & 98 & 102 & 100 & 100 \\
\hline 2. & Final setting time & 218 & 222 & 220 & 220 \\
\hline 3. & Consistency & 39 & 41 & 40 & 40 \\
\hline 4. & Soundnes s & 1.1 & 1.3 & 1.2 & 1.2 \\
\hline 5. & Fineness & 2.7 & 3.3 & 3.0 & 3.0 \\
\hline 6. & Specific gravity & 3.14 & 3.1 & 3.16 & 3.13 \\
\hline 7. & Compressive Strength: & & & & \\
& 1.3 Days & 24.08 & 22.7 & 24.43 & 23.736 \\
& 2.7 Days & 36.4 & 35.8 & 37.25 & 36.483 \\
& 3. 28 Days & 45.8 & 44.3 & 46.32 & 45.473 \\
\hline
\end{tabular}

\subsection{Tests on fly ash}

Table 5: Test results of clayey soil

\begin{tabular}{|l|l|l|l|l|l|}
\hline S. No. & Name of experiment & Observed value & Sample 3 & Average \\
\cline { 3 - 6 } & & Sample 1 & Sample 2 & Sample & 45.5 \\
\hline 1. & Consistency & 45 & 44.5 & 25.6 & 25 \\
\hline 2. & Fineness & 24.2 & 25.2 & 25 & \\
\hline
\end{tabular}


4.5. Compressive strength test results of brick sample

4.5.1. Casting of specimen 1:

Table 6: Compressive strength of specimen 1

\begin{tabular}{|l|l|l|l|l|l|}
\hline Foundry sand & Clayey soil & Cement & Water & Compressive load, inTon & Strength in N/mm \\
\hline $25 \%$ & $50 \%$ & $25 \%$ & $1000 \mathrm{ml}$ & 22.5 & 9.81 \\
\hline $1 \mathrm{~kg}$ & $2 \mathrm{~kg}$ & $1 \mathrm{~kg}$ & & & \\
\hline
\end{tabular}

\subsubsection{Casting of specimen 2:}

Table 7: Compressive strength of specimen 2

\begin{tabular}{|l|l|l|l|l|l|}
\hline Foundry sand & Clayey soil & Cement & Water & Compressive load, In Ton & Strength in N/mm $\mathbf{m}^{2}$ \\
\cline { 1 - 3 } $25 \%$ & $50 \%$ & $25 \%$ & $1000 \mathrm{ml}$ & 36 & 12.5 \\
\hline $1 \mathrm{~kg}$ & $2 \mathrm{~kg}$ & $1 \mathrm{~kg}$ & & & \\
\hline
\end{tabular}

\subsubsection{Casting of specimen 3:}

Table 8: Compressive strength of specimen 3

\begin{tabular}{|c|c|c|c|c|c|c|}
\hline Foundry sand & Clayey soil & Cement+ lime & Water & Flyash & Compressive strength, inTon & $\begin{array}{l}\text { Strength } \\
\mathrm{N} / \mathrm{mm}^{2}\end{array}$ \\
\hline $25 \%$ & $50 \%$ & $12.5 \%$ & \multirow[t]{2}{*}{$1370 \mathrm{ml}$} & $12.5 \%$ & \multirow[t]{2}{*}{-} & \multirow[t]{2}{*}{-} \\
\hline $1.25 \mathrm{~kg}$ & $2.5 \mathrm{~kg}$ & $\begin{array}{l}0.525 \mathrm{~kg} \\
+100 \mathrm{gm} \text { lime }\end{array}$ & & $0.625 \mathrm{~kg}$ & & \\
\hline
\end{tabular}

Result of specimen 3 = during extracting of brick from mould the brick was broken due to high moisture content and improper binding.

\subsubsection{Casting of specimen 4:}

Table 9: Compressive strength of specimen 4

\begin{tabular}{|l|l|l|l|l|l|l|}
\hline Foundry sand & Clayey soil & Cement & Water & Flyash & Compressive strength, in ton & Strength in N/mm \\
\hline $12 \%$ & $50 \%$ & $13 \%$ & & $12 \%$ & - & - \\
\cline { 1 - 2 } & $1.4200 \mathrm{~kg}$ & $0.42 \mathrm{~kg}$ & & \\
\hline
\end{tabular}

Result: During extracting of brick from mould the brick was broken due to excessive drying. 4.5.5. Casting of specimen 5:

Table 10: Compressive strength of specimen 5

\begin{tabular}{|c|c|c|c|c|c|c|c|}
\hline $\begin{array}{l}\text { Foundry } \\
\text { sand }\end{array}$ & Clay soil & Cement & Water & Flyash & Plasticizer & $\begin{array}{l}\text { Compressive strength, in } \\
\text { ton }\end{array}$ & $\begin{array}{l}\text { Strength in } \\
\mathbf{N} / \mathbf{m m}^{2}\end{array}$ \\
\hline $30 \%$ & $45 \%$ & $15 \%$ & \multirow{2}{*}{$\begin{array}{l}1200 \\
\mathrm{ml}\end{array}$} & $10 \%$ & \multirow[t]{2}{*}{$0.005 \mathrm{Kg}$} & \multirow[t]{2}{*}{16.5} & \multirow[t]{2}{*}{6.295} \\
\hline $1.05 \mathrm{~kg}$ & $1.575 \mathrm{~kg}$ & $0.525 \mathrm{~kg}$ & & $0.15 \mathrm{~kg}$ & & & \\
\hline
\end{tabular}

4.5.6. Casting of specimen 6:

Table 11: Compressive strength of specimen 6

\begin{tabular}{|c|c|c|c|c|c|c|c|}
\hline $\begin{array}{l}\text { Foundry } \\
\text { sand }\end{array}$ & Clay soil & Cement & Water & Fly ash & Plasticizer & $\begin{array}{l}\text { Compressive strength } \\
\text { in ton }\end{array}$ & $\begin{array}{l}\text { Strength } \\
\mathbf{N} / \mathbf{m m}^{2}\end{array}$ \\
\hline $33.33 \%$ & $11.67 \%$ & $15 \%$ & \multirow{2}{*}{$\begin{array}{l}1200 \\
\mathrm{Ml}\end{array}$} & $40 \%$ & \multirow[t]{2}{*}{$0.005 \mathrm{Kg}$} & \multirow[t]{2}{*}{290} & \multirow[t]{2}{*}{11.065} \\
\hline $1 \mathrm{~kg}$ & $0.350 \mathrm{~kg}$ & $0.45 \mathrm{~kg}$ & & $1.2 \mathrm{~kg}$ & & & \\
\hline
\end{tabular}

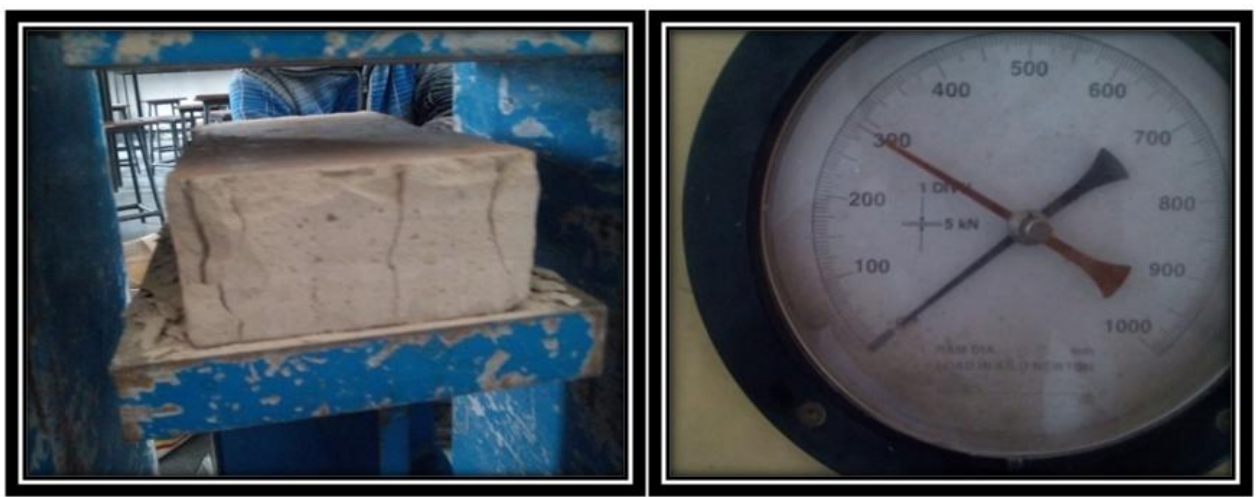

Figure 1: Compressive strength reading of specimen 6 


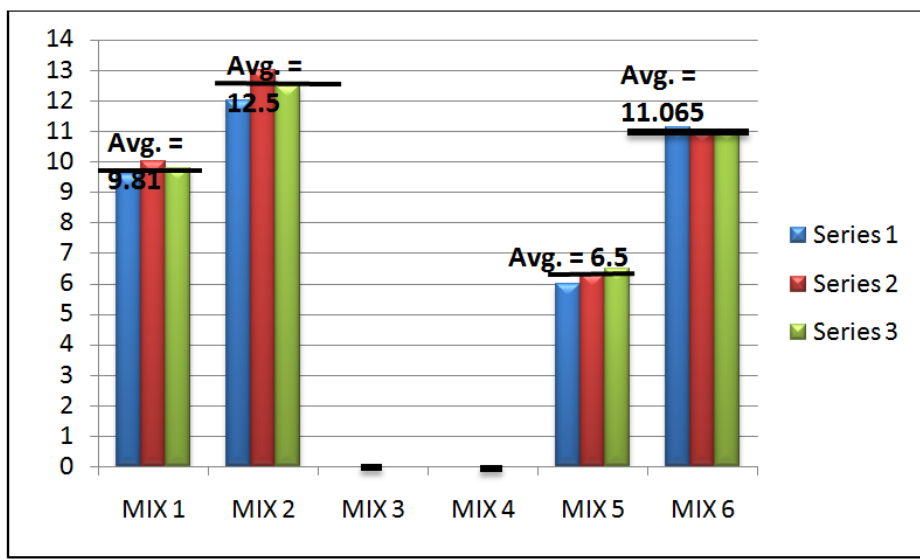

Figure 2: Compressive strength of brick samples at 5 days

\section{Conclusions}

\section{Conclusion}

The addition of foundry sand and cement to the brick mix gives a comparable value of compressive strength at 5 days testing, after casting when compared with the strength of class A brick. On the addition of $33.33 \%$ foundry sand and $15 \%$ of cement to the brick mix the strength obtained was $11.065 \mathrm{~N} / \mathrm{mm}^{2}$ viz. $110.65 \%$ greater than the conventional brick of class A which shows strength up to $10 \mathrm{~N} / \mathrm{mm}^{2}$.

It is observed from experiment result that as decrease in cement amount and clayey soil at the certain value ( $15 \%$ of cement and $11.67 \%$ of clay),with increasing in amount of fly ash and foundry sand, the compressive strength of brick sample increases.

Thus, from the experimental results we can conclude that:

- As the clay content reduces and foundry sand increases, compressive strength of specimen increases.

- The maximum compressive strength attained is at $40 \%$ of fly ash and $33.33 \%$ of foundry sand.

- Cost of the brick is reduced to Rs.4.5 in comparison of standard brick of Rs.8.

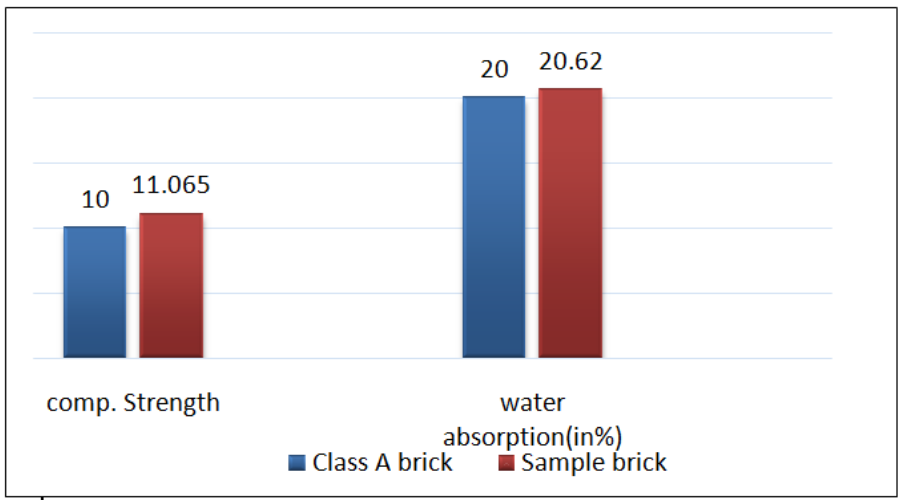

Figure 25: Comparison of strength and water absorption of brick sample with standard sample

\section{Cost analysis:}

1. Cement: Rs. $7 / \mathrm{kg}$

2. Flyash: Rs. $0.5 / \mathrm{kg}$

3. Admixture: Rs. 140 /litre

4. Foundry sand: Rs. 0

5. Clayey soil: Rs. $1600 / 2440 \mathrm{~kg}$

- Cost of standard sample (class A brick): Cost= Rs. $8 /$ brick

- Cost of brick with foundry sand, fly ash and cement:

Cost $=$ Rs. 4.5 / brick

Cost of saving $=$ Rs. $3.5 /$ brick 


\section{Acknowledgement}

In the sense of great pleasure and satisfaction we present this research. The completion of this project is no doubt a product of invaluable support and contribution of number of people. We are grateful to our lab assistants and classmates for their constant motivation and comments that has helped us to complete this report.

\section{References}

[1]. Amit Kumar D. Raval, Arti Pamnani, Alefiya I. Kachwala, Foundry sand: utilisation as a partial replacement of fine aggregate for establishing sustainable concrete, International Journal of Engineering Sciences \& Research Technology, ISSN: 2277-9655.

[2]. Akshay Satish More, Ahad Tarade, Ashwani Anant, Assessment of suitability of Fly Ash and Rice Husk Ash burnt clay bricks, International Journal of Scientific and Research Publications, Volume 4, Issue 7, July 2014, ISSN 2250-3153.

[3]. American Foundrymen's Society, AlternativeUtilization of Foundry Waste Sand, Final Report (Phase I) prepared by American Foundrymen's Society Inc. for Illinois Department of Commerce and Community Affairs, Des Plaines, Illinois, July, 1991.

[4]. DushyantRameshbhaiBhimani, Prof.Jayesh KumarPitroda, Prof.Jaydevbhai J. Bhavsar,Used foundry sand: opportunities for development of eco-friendly low cost concrete, International Journal of Advanced Engineering Technology, E-ISSN 0976-3945.

[5]. IS 4305:1967 Glossary of terms relating to pozzolana.

[6]. IS 5513:1996 Specification for Vicat apparatus.

[7]. IS 8112:1989 Specification for 43 grade ordinary Portland.

\section{Authors' profile}

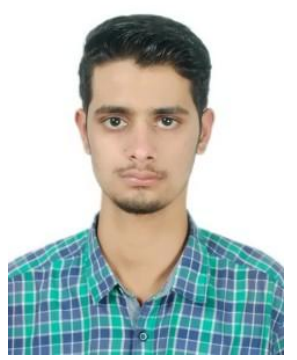

${ }^{[1]}$ Bhudev Pandey is final year student of civil engineering of 2017 batch of SRMCEM, Lucknow. He is keenly interested in researches. He has won $3^{\text {rd }}$ prize at technical fest of IIT- ROORKEE, COGNIZANCE, in PROTOTYPE, 2k15.

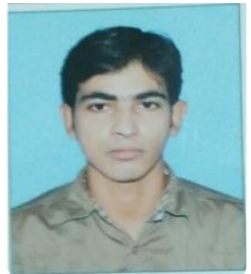

${ }^{[2]}$ Neelesh Kumar Singh is working as assistant professor in civil engineering department in SRMCEM. He is academically sound with master degree from MMMEC, Gorakhpur, he is specialized in seismic design and earthquake engineering. He received gold medal by C.M. of Uttar Pradesh, India for his academic performance and research. 